ACTA THERIOLOGICA

Vol. 21, 19: 267-278, 1976

\title{
Immunological Relationships of Sousliks Genus Citellus in the Povolgje Region
}

\author{
V. P. DENISOV \& N. I. SMIRNOVA
}

\begin{abstract}
Denisov V. P. \& Smirnova N. I., 1976: Immunological relationships of sousliks genus Citellus in the Povolgje region. Acta theriol., 21, 19: 267-278 [With 3 Tables \& 6 Figs.]

Immunological studies of the sousliks carried out by reactions of the hemolysis and hemagglutination, indicate that C. pygmaeus, C. suslicus, C. major and C. fulvus are characterized by relatively high content of the erythrocytic antigens, which are specific for each species. For these reasons it appears worth while to mention the serological difference observed between these species. In addition to the above specific characters results of the hemolysis and hemagglutination reactions may be advantageously employed in analysing the intraspecific structure of rodents.
\end{abstract}

[State University, 410001 Saratov, Astrahanskaja 83, USSR]

\section{INTRODUCTION}

The basis of the evolutionary process is the formation of the species, but it is difficult to obtain a knowledge of this without thorough and profound studies of interspecific distinctions and intraspecific structures. Most of investigations of this problem are based on an anaiysis of morphological resemblance or morphological distinction of the forms studied, and as a result, it is impossible to detect many of the specific features of the organism. Systematicians have therefore shown much interest in physiological, embryological, karyological, biochemical and other studies, which would permit, by means of discussion of controversial questions of taxonomy, of arriving at a mutual understanding of this problem. The most widespread methods are connected with studies of protein, in which hereditary information is developed. Valuable results are obtained by application of immunological reactions which are capable of identifying comparatively minor variations of antigen composition in the protein.

Numerous studies concerned with immunological methods have demonstrated the most productive and successful usage of serology in relation to the studies of various animal groups. Hemoagglutination 
and precipitation reactions are more often utilized in these studies (B oyden, 1926, 1942; A l t uhov, 1964, 1969; Lim anski, 1964, 1969; L ukjan enk o, 1966, 1971; Gerber, Birney, 1968; Kirs ch, 1968, 1973; Denisov \& Mozarova, 1970; Minton \& Salani$\mathrm{tro}, 1972 ; \mathrm{Zukov}, 1972,1973$ and others). Reactions of hemolysis (A i zava, Okuma \& Ishii, 1967; Lukjanenko, 1968), transplantation (S juzjumova, 1969, 1971; Dobrinskaja, 1973) and complement fixation test (Averkina, 1960; A mirhanov, 1968; Burdak, 1968) are less attractive, on account of their high sensitivity.

Immunological studies of sousliks of the Volga region are of great interest, for it is here (in particular in this territory), that one may observe adjacent areas of these species and the specific relations arising in these places of contacts. C. pygmaeus and C. suslicus inhabit the right bank of the Volga, the northern border of $C$. pygmaeus area coinciding with the southern border of the range of C. suslicus. Mixed colonies, in which hybrid forms usually predominate exist on the common boundaries of the two distribution areas of these rodents (D e n is ov, 1961, 1963). The reverse applies on the left bank of the Volga, where the northern border of distribution of $C$. pygmaeus and the southern border of $C$. major overlap each other. This zone is characterised either by a "pure" colony of $C$. pygmaeus or $C$. major, occupying areas with different vegetation cover, or by a mixed colony, with both species $C$. pygmaeus and C. major), but hybrids between them are fairly rare.

\section{MATERIAL AND METHODS}

Immunological relationships were investigated between the four speoies of Citellus Oken, 1816: C. pygmaeus (P alla s, 1779), C. suslicus (G üld., 1770), C. major (P a 1la s, 1779), and C. fulvus ( $\mathrm{Lich}$., 1823). Four populations of C pygmaeus were studied, two of which inhabited the right bank of the Volga in the regions of Elan (population $A$ ) and Kamyshin (population $B$ ) close to Volgograd, two on the left bank of the Volga in the region of Jablonja (population C) near Saratov and in the region of Samoilovka (population $D$ ) in the Volgograd district (Fig. 1).

Antigen relationships of studied species and populations were ascertained by means of hemolysis and hemagglutination reactions. Antisera were prepared according to Altubov's et al. (1964) method against the blood erythrocyte of C. major, C. suslicus and rodents from populations $A, B, C$ of $C$. pygmaeus. The $3 \%$ suspension of washed blood erythrocytes of sousliks, the complement (for hemolysis reaction) - fresh serum of guinea-pig blood diluted $1: 10$ and inactivated immune serum diluted from 1:10 up to 1:9000 were employed for set up reactions. Simultaneously tests were made for control of immune serum, antigen and complement. The reaction results were defined, an hour after the tubes had been placed in thermostat at a temperature $+37^{\circ} \mathrm{C}$, by the signs $(+)$ or $(-)$ cu:rently used in microbiology. The results obtained were converted to percentages 
according the formula of Boyden (1926), by which the titre value of homological reactions is taken as $100 \%$ and the titre heterological reaction estimated in relation to it. The antigen relation of the sousliks studied was also defined by immulogical distances calculated by the $\mathrm{M}$ a in a r di formula:

$$
\text { I.d. }=\frac{1}{(\mathrm{Oa}: E a)(\mathrm{Ob}: E b)}
$$

when $O b$ and $O a=$ the antibody titre against homological erytrocytes, $E a$ and $E b=$ the antibody titre against heterological erythrocytes, $a$ and $b-$ immune sera obtained against the erythrocytes species $a$ and $b$ respectively ( $M$ a in a rdi, 1957). In addition the generally accepted estimation of the results of hemolysis

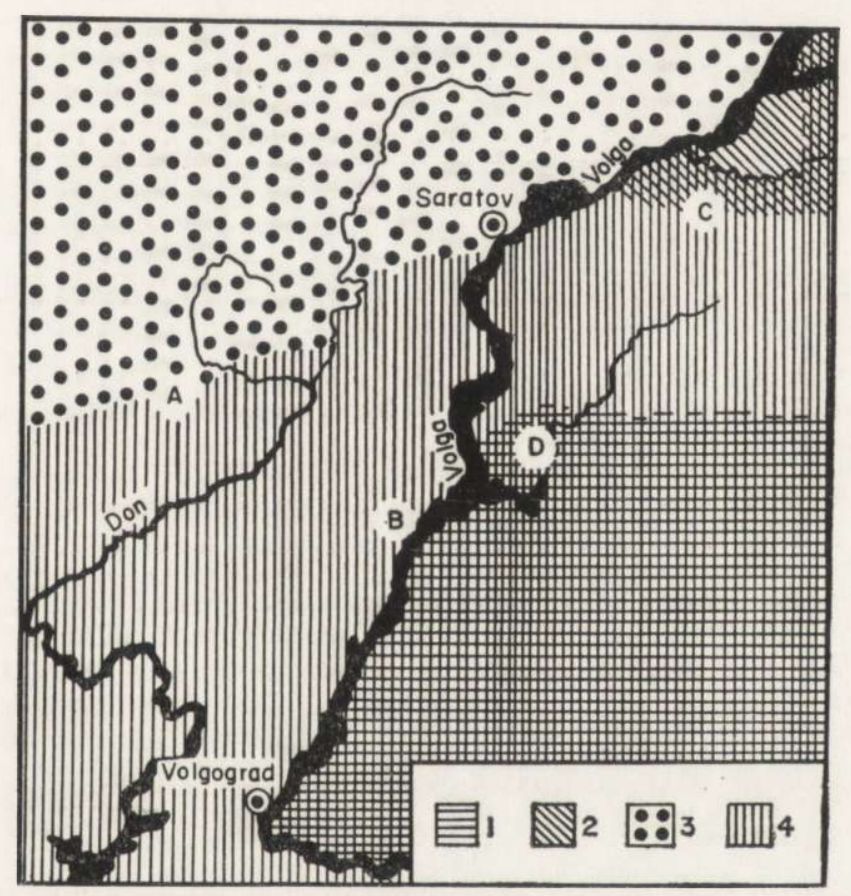

Fig. 1. Distribution of sousliks of genus Citellus in the Povolgje Region.

1 - C. fulvus, $2-$ C. major, $3-$ C. suslicus, $4-$ C. pygmaeus. A, B, C, D -investigated populations of C. pygmaeus.

reaction were treated on the photoelectrocolorimeter. The data obtained were expressed in percentages of the value corresponding to the total hemolysis. The total number of set up reactions was 1769 .

\section{RESULTS}

The reactions of hemolysis show statistically significant serological differences between the investigated species of sousliks and permit of finding antigen resemblance. Analysis of antiserum against erythrocytes 
of $C$. major blood revealed the erythrocytic proximity between $C$. major and $C$. fulvus. The complex of common erythrocytes of the latter is comparatively high $-72.2 \%$. C. pygmaeus and C. suslicus were more separated from $C$. fulvus by this values. The average titres in the reactions with erythrocytes of their blood were $53.2 \%$ and $44.2 \%$. The comparatively small differences between these two values reveals the relative proximity of these species to each other (Fig. 2a, Table 1).

Studies of immune serum against the blood erythrocytes of $C$. suslicus
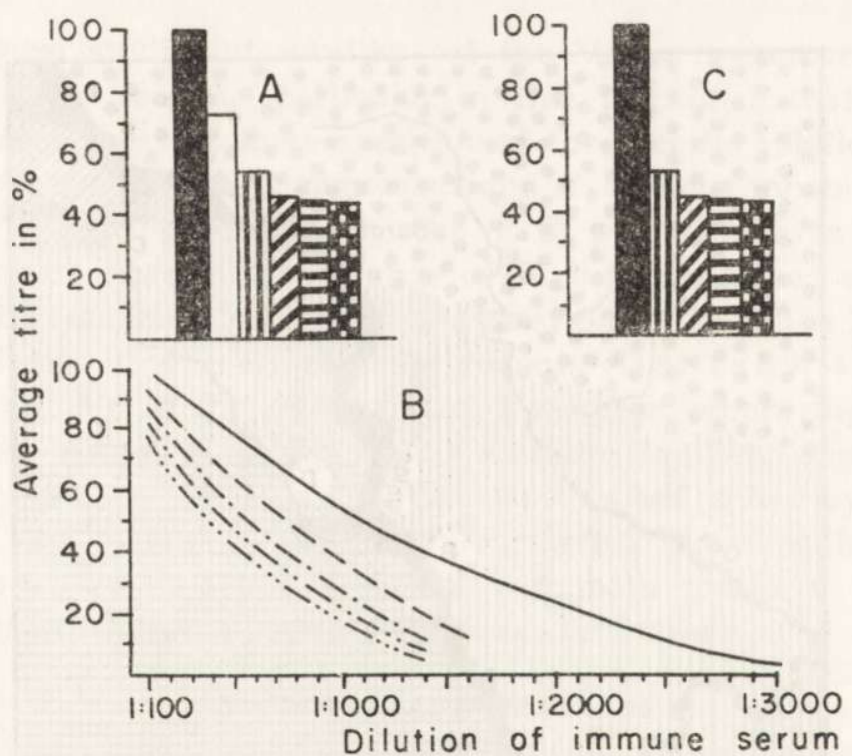

圆 $\square 2$ 而3 $\square_{4}$ 目 56 圈7

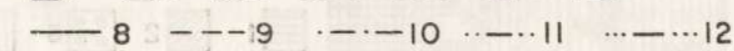

Fig. 2. Results of immunological reactions with antiserum againts the blood erythrocytes of C. major.

A - reaction of hemolysis; B - data of photoelectrocolorimetre; C - reaction of hemoagglutination; $1,8-$ C. major; $2-$ C. fulvus; $3,9-$ C. suslicus; $4,10-$ C. pygmaeus (population A); 5, $11-$ C. pygmaeus (population B); 6, $12-C$. pygmaeus (population C); $7-$ C. pygmaeus (population D).

showed that there are antigen distinctions between the studied species. The least titre $(40 \%)$ is observed in reactions with blood erythrocytes of $C$. fulvus, which demonstrates the immunological isolation of these species from C. suslicus, C. major possessed an intermediate titre which was slightly higher $-52.0 \%$. The greatest serological resemblance is observed between $C$. suslicus and $C$. pygmaeus - their antigen similar- 
ity is as high as $60.0 \%$ (Fig. 3a, Table 1). The immunological proximity of C. pygmaeus and C. suslicus is also observed in investigations of the antiserum against the blood erythrocytes of $C$. pygmaeus from the different populations: $A, B$ and $C$. The complex of the common antigens amounts to $72.4 \%, 66.0 \%$ and $64.5 \%$ respectively. C. major and $C$. fulvus

\section{Table 1}

Confidence intervals of differences $(p)$ of average titres between the investigated species and populations of sousliks (reaction of hemolysis).

C. m. - C.major; C.s. - C. susticus; C. p. - C. pygmaeus; A, B, C, D, - different populations, $n-$ not investigated.

\begin{tabular}{|c|c|c|c|c|c|}
\hline \multirow{2}{*}{$\begin{array}{l}\text { Species and populations } \\
(A, B, C, D) \text { of sousliks }\end{array}$} & \multicolumn{5}{|c|}{$\begin{array}{l}\text { Immune serum against the erythrocytes } \\
\text { of sousliks }\end{array}$} \\
\hline & C. $m$. & C. s., & C. p., $A$ & C. $p ., B$ & C. $p ., C^{-}$ \\
\hline C. major and C. fluvus & + & + & + & + & + \\
\hline C. major and C. suslicus & + & + & + & + & + \\
\hline C. major and C. pygmaeus, $A$ & + & + & + & + & + \\
\hline C. major and C. pygmaeus, $B$ & + & + & + & + & + \\
\hline $\begin{array}{l}\text { C. major and C. pygmaeus, } C \\
\text { C. major and } C \text {. pygmaelus, } D\end{array}$ & $\vec{n}$ & $\stackrel{+}{+}$ & + & $\stackrel{t}{+}$ & $\begin{array}{l}+ \\
+\end{array}$ \\
\hline $\begin{array}{l}\text { C. suslicus } \\
\text { and } C \text {. pyamaeus, } A\end{array}$ & & & & & \\
\hline $\begin{array}{l}\text { and C. pygmaeus, } A \\
\text { C. suslicus }\end{array}$ & + & + & + & + & + \\
\hline $\begin{array}{l}\text { and C. pygmaeus, B } \\
\text { C. suslicus }\end{array}$ & + & + & + & + & + \\
\hline $\begin{array}{l}\text { and C. pygmaeus, C } \\
\text { C. suslicus }\end{array}$ & + & + & + & + & + \\
\hline and C. pygmaeus, $D$ & $\mathrm{n}$ & + & + & + & + \\
\hline C. suslicus and C. fulvus & + & + & + & $\dot{+}$ & + \\
\hline $\begin{array}{l}\text { C. pygmaeus, } A \text { and } B \\
\text { C. pygmaeus, } A \text { and } D\end{array}$ & $\bar{n}$ & + & + & + & + \\
\hline $\begin{array}{l}\text { C. pygmaeus, } A \text { and } D \\
\text { C. pygmaeus, } A \text { and } C\end{array}$ & $\underline{\mathrm{n}}$ & $\stackrel{+}{+}$ & $\begin{array}{l}+ \\
+\end{array}$ & + & + \\
\hline $\begin{array}{l}\text { C. pygmaeus, } A \text { and } C \\
\text { C. pygmaeus, } A \\
\text { and } C \text { fulvus }\end{array}$ & & & & & \\
\hline $\begin{array}{l}\text { and C. fulvus } \\
\text { C. pygmaeus, B and D }\end{array}$ & $\begin{array}{l}+ \\
\mathrm{n}\end{array}$ & $\begin{array}{l}+ \\
+\end{array}$ & + & + & $\begin{array}{l}+ \\
+\end{array}$ \\
\hline $\begin{array}{l}\text { C. pygmaeus, } B \text { and } D \\
\text { C. pygmaeus, } B \text { and } C\end{array}$ & - & + & + & + & $\stackrel{+}{+}$ \\
\hline $\begin{array}{l}\text { C. pygmaeus, } C \text { and } D \\
\text { C. pygmaeus, } C\end{array}$ & $\mathrm{n}$ & - & - & - & + \\
\hline $\begin{array}{l}\text { and } C \text {. fulvus } \\
\text { C. pygmaeus, } D\end{array}$ & + & + & + & + & + \\
\hline $\begin{array}{l}\text { C. pygmaeus, } D \\
\text { and C. fulvus }\end{array}$ & $\mathrm{n}$ & + & + & + & + \\
\hline \multicolumn{6}{|c|}{+ differences statistically significant; - differences statistically non-significant } \\
\hline \multicolumn{6}{|c|}{$\begin{array}{l}\text { are more distant species from } C \text {. pygmaeus. The serological similarity } \\
\text { is negligible, especially between } C \text {. pygmaeus and } C \text {. fulvus. In this case } \\
\text { C. major and C. fulvus immunologically are isolated from each other } \\
\text { (Fig. } 4 \mathrm{a}, 5 \mathrm{a}, 6 \mathrm{a} \text {; Table } 1 \text { ). } \\
\text { A clear picture is observed when hemolysis reactions are treated on } \\
\text { the photoelectrocolorimeter. The clear immunological distinction of } \\
\text { C. pygmaeus, C. suslicus and C. major from each other can be traced }\end{array}$} \\
\hline
\end{tabular}


in all dilutions of antiserum. At the same time the diagrams reflecting the results of hemolysis with all the immune sera show that C. pygmaeus and C. suslicus are closer to each other than the compared species. C. major is markedly different from the latter, as is more clearly

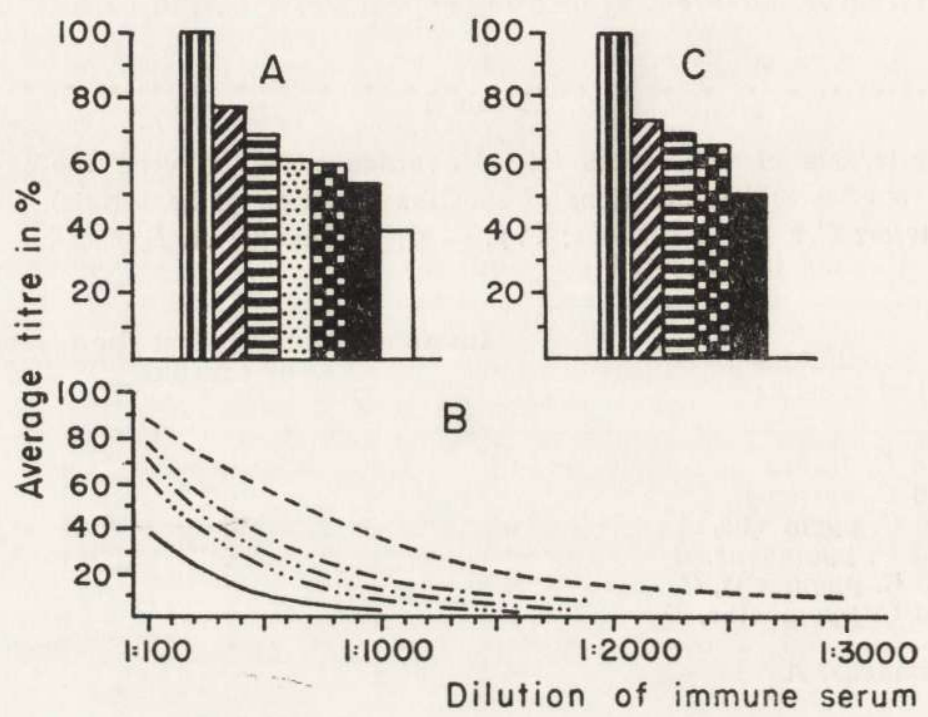

Fig. 3. Results of immunological reactions with antiserum against the blood erythrocytes of C. suslicus. Explanations see fig. 2.

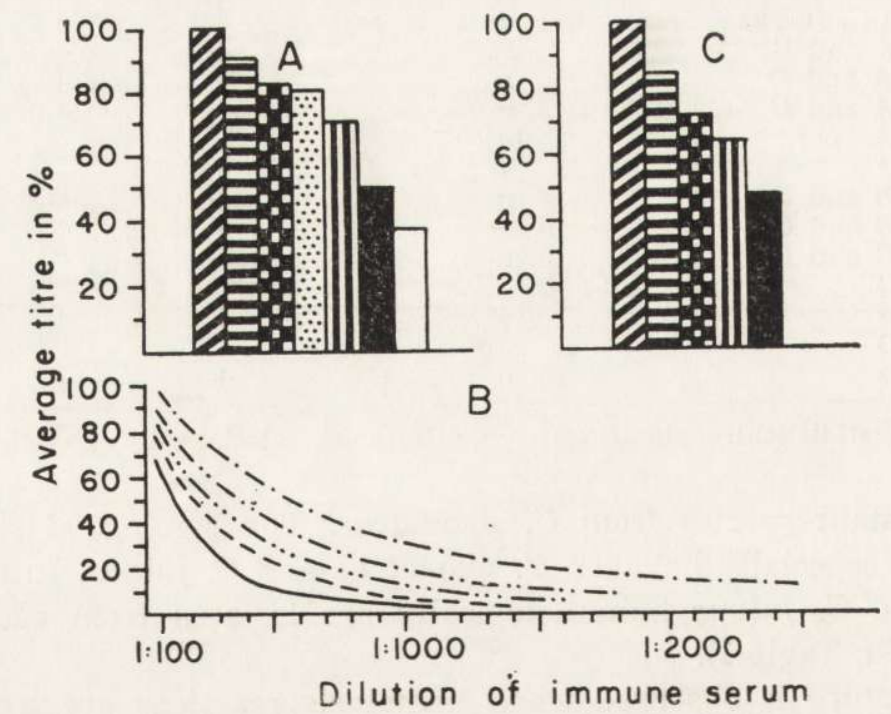

Fig. 4. Results of immunological reactions with antiserum against the blood erythrocytes of C. pygmaeus (population A). Explanations see fig. 2. 
revealed in analyses of the antiserum against the blood erythrocytes of the same species (Fig. 1b, 2b, 3b, 4b, 5b).

The results of the hemoagglutination reactions of the immune serum with the blood erythrocytes C. major, C. suslicus and C. pygmaeus

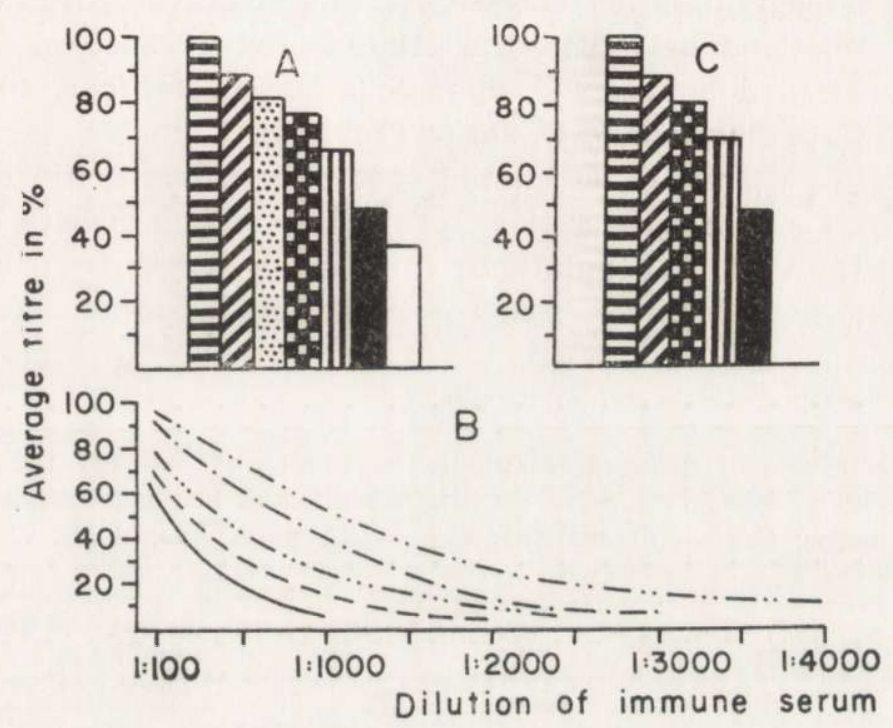

Fig. 5. Results of immunological reactions with antiserum against the blood erythrocytes of C. pygmaeus (population B). Explanations see fig. 2.

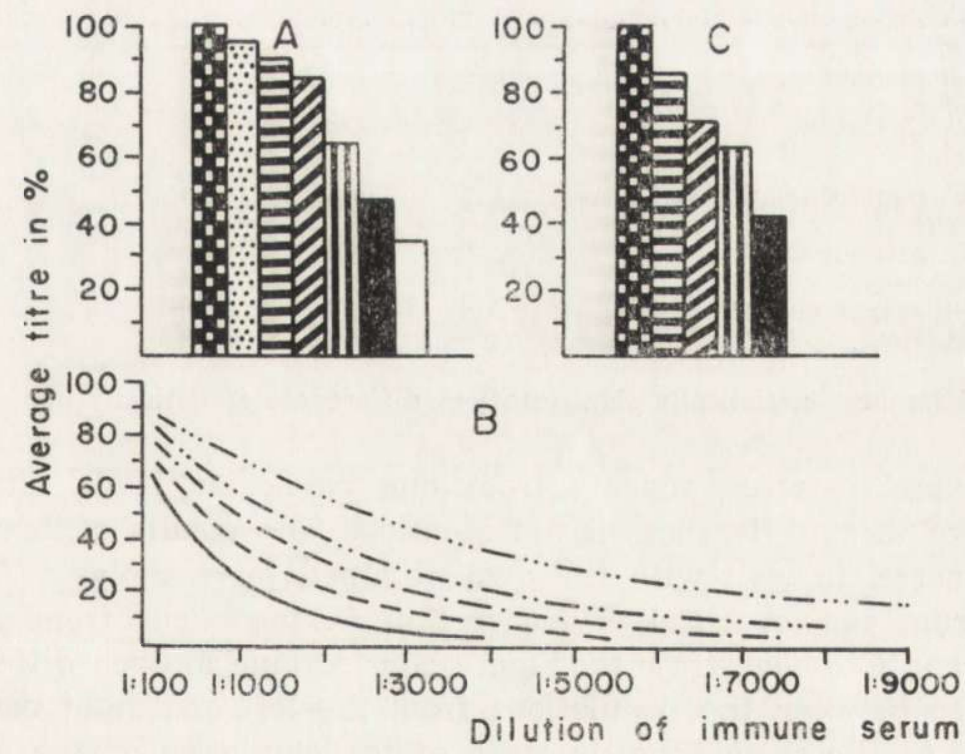

Fig. 6. Results of immunological reactions with antiserum against the $C$. pygmaeus (population C). Explanations see fig. 2. 
coincide with the data of the hemolysis. Of the species investigated, $C$. pygmaeus and C. suslicus are serologically closer to each other (Fig. 1c, $2 \mathrm{c}, 3 \mathrm{c}, 4 \mathrm{c}, 5 \mathrm{c}$; Table 2).

Immunological distances calculated according to the results of hemolysis and hemoagglutination cross-reactions confirm the established serological relations between the studied rodent species. The least distances are noted between $C$. pygmaeus and $C$. suslicus, and greatest - between C. pygmaeus and C. major (Table 3).

The studies permit of estimating not only interspecific differences, but also blood erythrocyte antigen properties of one species of animals taken from the various populations. In so doing, erythrocyte differences are observed both between sousliks inhabiting opposite banks of the

\section{Table 2}

Confidence intervals of differences $(p)$ of average titres between the investigated species and populations of sousliks (reaction of hemoagglutination).

C. m. - C. major; C.s. - C. suslicus; C. p. - C. pygmaeus; A, B, C - different populations.

\begin{tabular}{|c|c|c|c|c|c|}
\hline \multirow{2}{*}{$\begin{array}{l}\text { Species and populations } \\
(A, B, C) \text { of sousliks }\end{array}$} & \multicolumn{5}{|c|}{ Immune serum against the erythrocytes } \\
\hline & C. $m$. & C.s., & C. p., $A$ & C. $p ., B$ & C. p., C \\
\hline C. major and C. suslicus & + & + & + & + & + \\
\hline $\begin{array}{l}\text { C. major } \\
\text { and C. pygmaeus, A }\end{array}$ & + & + & + & + & + \\
\hline C. major & + & + & + & + & + \\
\hline $\begin{array}{l}\text { C. major } \\
\text { and C. pygmaeus, C } \\
\text { C. suslicus }\end{array}$ & + & + & + & + & + \\
\hline $\begin{array}{l}\text { and C. pygmaeus, } A \\
\text { C. suslicus }\end{array}$ & + & + & + & + & + \\
\hline $\begin{array}{l}\text { and C. pygmaeus, B } \\
\text { C. suslicus }\end{array}$ & + & + & + & + & + \\
\hline $\begin{array}{l}\text { and } C \text {. pygmaeus, } C \\
C \text {. pumaeus, } A \text { and } B\end{array}$ & \pm & + & + & $\stackrel{+}{+}$ & $\stackrel{t}{+}$ \\
\hline $\begin{array}{l}\text { C. pygmaeus, } A \text { and } B \\
\text { C. pygmaeus, } A \text { and } C\end{array}$ & + & + & + & + & + \\
\hline C. pygmaeus, B and C & - & + & + & + & + \\
\hline
\end{tabular}

+ differences statistically significant; - differences statistically non-significant.

Volga and between rodents from one particular bank, although the value of these differences is not identical. The results of hemoagglutination correlate well with the data obtained for hemolysis. Analysis of antiserum against blood erytrocytes of $C$. pygmaeus from populations $A, B$, and $C$ demonstrate that more considerable antigen differences are detected between the populations from the left and right banks of the Volga. At the same time, in spite of the similarity of the populations from the right bank, they are characterized by antigen specificity in 
relation to each other. Immunological distances also reveal antigen differences between the studied populations of C. pygmaeus (Fig. 4, 5, 6; Table 1, 2, 3).

\section{DISCUSSION}

Analysis of results of immunological investigations show that the studied species of sousliks are characterized by relatively high contents of erythrocytic antigens which are common to the genus Citellus as a whole. In addition the complex of antigens, specific to each species is established. C. pygmaeus and $C$. suslicus are characterized of the most total antigen complex that in itself is evidence of their resemblance. There is only a small degree of immunological similarity between them and C. major. C. fulvus and immunologically isolated species, is the closest to $C$. major of all the rodents studied. The results of the

Table 3

Immunological distances between the studied species and population of the sousliks.

\begin{tabular}{|c|c|c|c|c|}
\hline \multirow{2}{*}{$\begin{array}{l}\text { Species and populations } \\
\text { of the sousliks }\end{array}$} & \multicolumn{2}{|c|}{ Hemolysis } & \multicolumn{2}{|c|}{ Hemoagglutination } \\
\hline & $\bar{X}+m_{\mathrm{X}}$ & S. D. & $\overline{\mathbf{X}}+m_{\mathbf{X}}$ & S. D. \\
\hline C. pygmaeus, $A$ and $B$ & $1.192 \pm 0.015$ & 0.101 & $1.200 \pm 0.020$ & 0.085 \\
\hline C. pygmaeus, $C$ and $B$ & $1.265 \pm 0.016$ & 0.075 & $1.240 \pm 0.031$ & 0.132 \\
\hline C. pygmaeus, $C$ and $A$ & $1.305 \pm 0.009$ & 0.073 & $1.251 \pm 0.020$ & 0.082 \\
\hline $\begin{array}{l}\text { C. pygmaeus, } A \\
\text { and C. suslicus } \\
\text { C. pygmaeus, } B\end{array}$ & $1.445 \pm 0.017$ & 0.106 & $1.343 \pm 0.012$ & 0.055 \\
\hline $\begin{array}{l}\text { C. pygmaeus, } B \\
\text { and C. suslicus } \\
\text { C. pygmaeus, } C\end{array}$ & $1.560 \pm 0.024$ & 0.024 & $1.382 \pm 0.014$ & 0.060 \\
\hline and C. suslicus & $1.640 \pm 0.009$ & 0.054 & $1.492 \pm 0.036$ & 0.161 \\
\hline $\begin{array}{l}\text { C. suslicus and C. major } \\
\text { C. pygmaeus, A }\end{array}$ & $1.710 \pm 0.021$ & 0.132 & $1.605 \pm 0.035$ & 0.147 \\
\hline $\begin{array}{l}\text { and C. major } \\
\text { C. pygmaeus, B }\end{array}$ & $1.830 \pm 0.022$ & 0.171 & $1.781 \pm 0.036$ & 0.151 \\
\hline $\begin{array}{l}\text { and C. major } \\
\text { C. pygmaeus, C }\end{array}$ & $1.930 \pm 0.055$ & 0.401 & $1.803 \pm 0.064$ & 0.270 \\
\hline and C. major & $1.935 \pm 0.033$ & 0.225 & $1.870 \pm 0.058$ & 0.244 \\
\hline
\end{tabular}

immunological investigations are completely correlated with results obtained by precipitation (Denisov \& Mozarova, 1970) and phytohemoagglutination (S mirnova, 1974) reactions and confirm the morphological, physiological, hybrization and paleontological data. Morphological analyses show that of all the species compared C. pygmaeus and $C$. suslicus are the closest. These species, clearly distinguished by the colour of their fur, have many almost similar morphological indexes (O gnev, 1947; Gromov et al. 1963; Denisov, 1963).

The absence of reproductive isolation between C. pygmaeus and $C$. suslicus results in their resemblance being considerable and consequent- 
ly the zone of interspecific hybridization is situated where the ranges of these species overlap. In this case mating is not connected with sterility or complete lack of vitality because offspring, not only of the first generation, are known to occur. The peculiarity of hybridization is its introgressive character. C. pygmaeus absorbs C. suslicus and expands its range in this way (Denisov, 1961, 1963). At the same time hybrids very seldom occur in the places of common inhabitation of $C$. pygmaeus, C. major and C. fulvus (B o zanov, 1944, 1945; Denis o v, 1964).

The degree of serological resemblance between $C$. pygmaeus and $C$. major is small. C. fulvus, an immunologically isolated species, is nevertheless closer to $C$. major than the rodents studied.

The population differences of the erythrocytic antigens suggest the geographical remoteness of the investigated populations. The serological differences between the populations of $C$. pygmaeus from the left and right banks of the Volga are due to the fact that the river forms an unsurmountable barrier for sousliks, preventing a gene exchange between populations inhabiting the opposite banks.

The immunological investigations made show that the studied species of sousliks genus Citellus are characterized by relatively high content of erythrocytic antigen, specific for every species, with the result that it is justifiable to speak about serological differences between them. In addition to establishing the particular properties of a species, the reactions of hemolysis and hemoagglutination may be used in studies of intraspecific structure.

\section{REFERENCES}

1. Aizava K., Okuma K. \& Ishii H., 1967: Serological and immunological studies of the blood of numbers of the Chiroptera. Further experiments with respect to the significance of immune hemagglutination and heterogenetic hemolysis in the classification of the bat. Nihon. Univ. J. Med., 9, 1: 87-96.

2. Altuhov J. P., 1964: Citofizjologičeskij i serologičeskij analiz vnutrividovoj differencjacji stavridy Cernogo morja. [In: »Kletka i temperatura sredy «]. Izd. Nauka: 235-238. Moskva.

3. A $1 \mathrm{tuh}$ ov J. P., 1969: Ob immunogenetičeskom podhode $\mathrm{k}$ probleme vnutrividovoj differencjacji u ryb. [In: „Uspehi sovremennoj genetiki«]. Izd. Nauka, 2: 161-195. Moskva.

4. Altuhov J. P., Apekin V. S. \& Limanskij V. V., 1964: Osnovnye principy issledovanija vnutri- i mežvidovoj differencjacji u ryb serologičeskimi metodami. Trudy azov.-chernomorsk. Inst. i Inst. morsk. ryb. Khoz. Okeanogr., 22: 53-71.

5. Amirhanov G. A., 1968: Opyt primenenija reakcji svjazanija komplementa (RSK) v celjah vyjasnenija vnutrividovoj differencjacji ryb. Vop. Ikhtiol., 8, 1: $190-193$. 
6. Averkina R. F., 1960: Sravnitel'noe izučenie antigennyh svojstv tkanej serdca raznyh vidov životnyh i čeloveka. Ź. obšč. Biol., 21, 3: 206-212.

7. B a ž a n ov V. S., 1944: Gibridy suslikov. DAN SSSR, 42, 7: 321-322.

8. B a ž a n ov V. S., 1945: K sistematike dvuh vidov suslikov iz Kazahskoj SSR. Vest. Kazah. fil. AN SSSR, 5, 8: 37-39.

9. Boyden A., 1926: The precipition reaction in the study of animal relationships. Biol. Bull., 50, 1: 73-107.

10. Boyden A., 1942: Systematic serology: a critical application. Physiol. Zöol., 15, 2: $109-145$.

11. B urdak V. G., 1968: O vnutrividovyh formah nekotoryh černomorskih ryb na osnove serologičeskih issledovanij. [In: »Biologičeskie issledovanija Cernoho morja i eho promyslovye resursy\&]. Izd. Nauka: 174-178. Moskva.

12. Den is ov V. P., 1961: Otnošenija malogo i krapčatnogo suslikov na styke in arealov. Zool. Z̈., 40, 7: 1079-1985.

13. Den is ov V. P., 1963: O gibridizacji vidov roda Citellus Oken. Zool. Ž., 42, 12: $1887-1889$.

14. Denisov V. P., 1964: Rasprostranienije malogo (Citellus pygmaeus Pallas) i riževatogo (Citellus major Pallas) suslikov v Zavolže. Nauč. Dokl. Vysšej. Sk., Biol. Nauki, 2: 49-54.

15. Denisov V. P. \& Možarova V. A., 1970: Izučenie immunobiologið̌eskogo rodstva suslikov roda Citellus Oken. metodom reakcji precipitacji na agare. [In: »Vop. Fizjol. i populjacionnoj ekologii«], 1: 45-50. Saratov.

16. Gerber I. \& Birney E., 1968: Immunological comparisons of four subgenera of ground squirrels. Syst. Zool., 17, 4: 413-416.

17. Gromov I. M., Bibkov D. I., Kalabukhov N. I. \& Meier M. N., 1965: Mlekopitajuščie. Fauna SSSR, 3, 2: Moskva.

18. Kirsch I., 1968: Prodromus of comparative serology of Marsupialia. Nature, 217, 5127: 418-420.

19. Kirsch I., 1973: The serology of mammals. Austral. Natur. Hist., 17, 9: $301-304$.

20. Limanskij V. V., 1964: Analiz vnutrividovoj differencjacji nekotoryh ryb Cernogo i Azovskogo morej pri pomošči reakcji precipitacji. Trudy azov.-chernomorsk. Inst. i Inst. morsk. ryb. Khoz. Okeanogr., 22: 31-37.

21. Limanskij V. V., 1969: Izučenie eritrocitarnyh antigenov atlantičeskih ančousov zapadnogo poberežja Afriki. Vop. Ihtiol., 9, 2: 366-369.

22. Lukjanenko V. I., 1966: O mežvidovoj differencjacji eritrocitarnyh antigenov u osetrovyh ryb. Ž. obšč. Biol., 27, 6: 723-727.

23. Lukjanenko V. I., 1968: Immunobiologičeskaja harakteristika dvuh sistematičeski blizkih vidov lososevyh ryb. Vop. Ihtiol., 8, 1: 39-44.

24. L u k j a n en k o V. I., 1971: Immunobiologija ryb. Moskva.

25. Mainardi D., 1959: Immunological distances among some gallinaceous birds. Nature, 184, 4690, Suppl. 12: 913-914.

26. Minton Sh. A. \& Salanitro S. K., 1972: Serological relationships among some colubrid snakes. Copeia: $246-252$.

27. O gnev S. I., 1947: Zveri SSSR i priležaščih stron. 4. Izd. AN SSSR. Moskva.

28. Sjuzjumova L. M., 1969: Vidovaja specifiěnost' v projavlenii antigennyh svojstv tkanej pri reakcji na geterotransplantat. [In: „Voprosy evoljucionnoj i populjacionnoj ekologii životnyh«]. Izd. UFAN SSSR: 113-124. Sverdlovsk.

29. Sjuzjumova L. M., 1971: Vuntrividovye osobennosti tkanevoj sovmest:mosti u polevok $\mathrm{v}$ svjazi s genetičeskoj strukturoj ih populjacji i nekotorymi 
voprosami mikroevoljucji. Avtoref. na soisk. učenoj stepeni dokt. biol. nauk. Sverdlovsk.

30. Smirnova N. I., 1974: Izučenie analitičeskih osobennosti eritrocitov krovi suslikov Povolžja po reakcii fitogemaggljutinacii. Nauč. Dokl. Vysš. Š., Biol. Nauki, $6: 31-32$.

31. Ž u kov V. V., 1972: Immunologičeskoe vzaimootnošenie nekotoryh form podsemejstva Microtinae. [In: Sb. »Teriologija«]. Izd. Nauka, 2: 26-27. Novosibirsk.

32. $\mathrm{Z} u k \circ \mathrm{v}$ V. V., 1973: Estestvennye gemaggljutininy krovi nekotoryh polevok (Rodentia, Microtinae). Zool. Ž., 52, 4: 622-625.

Accepted, March 20, 1975.

\section{P. DENISOV i N. I. SMIRNOVA}

\section{IMMUNOLOGICZNE POKREWIENSSTWO SUSEOW Z RODZAJU CITELLUS, ZAMIESZKUJĄCYCH POWOEŻE}

\section{Streszczenie}

Przeprowadzono badania nad susłami z rodzaju Citellus Ok e n, 1816, zamieszkującymi obszary Powołża (Ryc. 1). Użyto metod immunologicznych - hemolizy i hemoaglutynacji - które wskazały, że C. pygmaeus, C. suslicus, C. major $i$ C. fulvus charakteryzują się względnie wysoką zawartością antygenów erytrocytowych, specyficznych dla każdego z gatunków (Ryc. 2-6). Należy przy tym podkreślić serologiczne zróżnicowanie jakie ujawnia się pomiędzy poszczególnymi gatunkami (Tabele $1-3$ ). Trzeba jeszcze dodać, że przedstawiona metodyka może być także wykorzystana przy badaniu wewnątrzgatunkowego zróżnicowania populacji gryzoni. 